\title{
Early experience with implant based breast reconstruction for early breast cancer in ptotic breasts with non biological mesh and lower pole dermal sling
}

\author{
Rathinasabapathy Rathinaezhil", Fiammetta Ugolini and Hisham Osman
}

\begin{abstract}
Aim: Evaluation of early experience with implant based breast reconstruction for early breast cancer in ptotic breasts with titanium coated polypropylene mesh and lower pole dermal sling.

Methods: A pilot prospective ongoing study where patients having immediate implant based reconstruction with non biological mesh and lower pole dermal sling are evaluated simultaneously. Patient, surgical, and tumour related factors are presented as well as the cosmetic outcome in five patients, two of whom underwent bilateral procedure for bilateral breast cancer and one who underwent simultaneous symmetrisation with reduction mammoplasty on the contralateral side.

Results: All five patients had good cosmetic outcome with minor complications. There was no delay in adjuvant treatment due to complications. All were satisfied with their results and would recommend this treatment to others.

Conclusion: Using a non biological mesh as well as a lower pole dermal sling, which covers the suture line and offers an extra layer of protection to the mesh, reduces the complication rate especially in patients who may be at higher risk of wound related problems such as those with increased body mass index. This procedure is also cost effective (non biological meshes are only 1/5th of the cost compared to biological meshes) and provides equivalent cosmetic outcomes in a select group of patients.
\end{abstract}

Keywords: Breast cancer, Reconstruction, Implant, Mesh, Lower pole dermal sling

\section{Background}

The incidence of breast cancer continues to increase throughout the world. In 2011, there were 50,285 new cases of breast cancer in the UK. 49,936 (99 \%) in women and 349 (less than $1 \%$ ) in men [1]. Patients with early breast cancer who need to undergo mastectomy are offered immediate as well as delayed reconstruction routinely in the UK. Nearly $30 \%$ of patients (national mastectomy breast reconstruction (NMBRA) audit) in the immediate reconstruction setting opted to have implant based reconstruction after weighing up all the options available to them. With the availability of various biological and

\footnotetext{
* Correspondence: rrathinaezhil@nhs.net

Park Centre for Breast Care, Brighton and Sussex University Hospitals NHS Trust, 177 Preston Road Brighton, East Sussex BN1 6AG, UK
}

non biological meshes, good cosmetic outcome can be achieved at the present time [2].

The cost of biological meshes can be a prohibitive factor in offering this to all patients requiring implant based reconstruction [3]. Non biological meshes as an alternative are cost effective and can be substituted for biological meshes [4].

There are several publications supporting the use of non biological meshes and claiming equivalent cosmetic outcomes to biological meshes [5-8]. In patients with significant ptosis where skin reduction is also necessary, a lower pole dermal sling (the patient's own biological mesh) can be used for breast reconstruction $[9,10]$.

We would like to present our early experience of combining the non biological mesh with the lower pole dermal sling in patients with significant ptosis who need skin 
Table 1 Patient related factors

\begin{tabular}{|c|c|c|c|c|c|}
\hline & Patient 1 & Patient 2 & Patient 3 & Patient 4 & Patient 5 \\
\hline Age & 42 & 47 & 55 & 59 & 62 \\
\hline BMl & 22 & 34 & 26 & 31 & 33 \\
\hline Smoking habit & Non smoker & $\begin{array}{l}\text { Yes. Gave up at } \\
\text { diagnosis }\end{array}$ & $\begin{array}{l}\text { Yes. Gave up at } \\
\text { diagnosis }\end{array}$ & $\begin{array}{l}\text { Ex-smoker-stopped } \\
15 \text { years ago }\end{array}$ & Non smoker \\
\hline Alcohol intake per week & Very occasional & None & Occasional & 14 units/week & None \\
\hline Drugs including steroids & None & None & None & None & None \\
\hline $\begin{array}{l}\text { Connective tissue and vasculitic } \\
\text { disorders }\end{array}$ & None & None & None & None & None \\
\hline Diabetes & No & No & No & No & No \\
\hline Other co morbidities & None & Asthma & None & None & None \\
\hline Skin quality & Very good & Good & Good & Good & Good \\
\hline Degree of ptosis & 3 & 3 & 2 & 3 & 3 \\
\hline Contra lateral breast surgery & Planned & NA & Patient not keen & $\begin{array}{l}\text { Reduction for } \\
\text { symmetry }\end{array}$ & Planned \\
\hline $\begin{array}{l}\text { Knowledge about post- } \\
\text { operative radiotherapy }\end{array}$ & $\begin{array}{l}\text { Aware of the } \\
\text { possibility }\end{array}$ & $\begin{array}{l}\text { Aware of the possibility } \\
\text { on the right }\end{array}$ & Aware & Unlikely as DCIS & $\begin{array}{l}\text { Aware of the possibility } \\
\text { on both sides }\end{array}$ \\
\hline
\end{tabular}

BMI body mass index, DCIS ductal carcinoma in situ

reduction as well as reconstruction using implants with good cosmetic outcome.

\section{Patient details and methods}

All patients consented to take part in the study and this study was fully compliant with the Helsinki declaration.
The treatment that patients underwent was the standard of care for their disease and as this study only looks into an innovative surgical technique, ethics approval was not required.

We have done seven procedures in five patients (two bilateral procedures for bilateral breast cancer). The age distribution in this cohort was 42-62 and the mean age

Table 2 Surgery related factors

\begin{tabular}{|c|c|c|c|c|c|}
\hline & Patient 1 & Patient 2 & Patient 3 & Patient 4 & Patient 5 \\
\hline Antibiotic prophylaxis $^{a}$ & Yes & Yes & Yes & Yes & Yes \\
\hline $\begin{array}{l}\text { Duration of antibiotic } \\
\text { prophylaxis }^{b}\end{array}$ & 7 days & 14 days & 7 days & 7 days & 10 days \\
\hline Skin prep used & Chlorhexidine & Chlorhexidine & Chlorhexidine & Chlorhexidine & Chlorhexidine \\
\hline $\begin{array}{l}\text { Method of dissection to } \\
\text { raise skin flaps and dermal } \\
\text { sling }\end{array}$ & Diathermy & Diathermy & Diathermy & Diathermy & Diathermy \\
\hline Cavity wash out & $\begin{array}{l}\text { Saline and antibiotic } \\
\text { solution }\end{array}$ & $\begin{array}{l}\text { Saline and antibiotic } \\
\text { solution }\end{array}$ & $\begin{array}{l}\text { Saline and antibiotic } \\
\text { solution }\end{array}$ & $\begin{array}{l}\text { Saline and antibiotic } \\
\text { solution }\end{array}$ & $\begin{array}{l}\text { Saline and antibiotic } \\
\text { solution }\end{array}$ \\
\hline $\begin{array}{l}\text { Change of gloves prior to } \\
\text { implantation }\end{array}$ & Yes & Yes & Yes & Yes & Yes \\
\hline Implant type & $\begin{array}{l}\text { Permanent } \\
\text { anatomical fixed } \\
\text { volume implant }\end{array}$ & $\begin{array}{l}\text { Permanent } \\
\text { anatomical fixed } \\
\text { volume implant }\end{array}$ & $\begin{array}{l}\text { Permanent } \\
\text { anatomical fixed } \\
\text { volume implant }\end{array}$ & $\begin{array}{l}\text { Permanent } \\
\text { anatomical fixed } \\
\text { volume implant }\end{array}$ & $\begin{array}{l}\text { Permanent } \\
\text { anatomical fixed } \\
\text { volume implant }\end{array}$ \\
\hline \multirow{3}{*}{$\begin{array}{l}\text { Type, number of drains } \\
\text { used and duration }\end{array}$} & Exudrain & Exudrain & Exudrain & Exudrain & Exudrain \\
\hline & 2 & 2 & 2 & 2 & 2 on each side \\
\hline & 7 days & 10 days & 7 days & 7 days & 10 days \\
\hline Laminar flow usage & Yes & Yes & Yes & Yes & Yes \\
\hline Post-op follow up & 1 week & 2 weeks & 1 week & 1 week & 1 week \\
\hline \multirow{2}{*}{$\begin{array}{l}\text { Mastectomy specimen } \\
\text { weight }\end{array}$} & \multirow[t]{2}{*}{$496 \mathrm{~g}$} & $\mathrm{R}-905 \mathrm{~g}$ & \multirow[t]{2}{*}{$600 \mathrm{~g}$} & \multirow[t]{2}{*}{$1071 \mathrm{~g}$} & $\mathrm{R}-454 \mathrm{~g}$ \\
\hline & & $L-885 g$ & & & $L-464 g$ \\
\hline
\end{tabular}


Table 3 Hospital stay and complications within 30 days

\begin{tabular}{llllll}
\hline & Patient 1 & $\begin{array}{l}\text { Patient } \\
2\end{array}$ & $\begin{array}{l}\text { Patient } \\
3\end{array}$ & $\begin{array}{l}\text { Patient } \\
4\end{array}$ & $\begin{array}{l}\text { Patient } \\
5\end{array}$ \\
\hline $\begin{array}{l}\text { No of nights spent in } \\
\text { hospital }\end{array}$ & 5 & 10 & 3 & 5 & 3 \\
$\begin{array}{l}\text { Inpatient concerns } \\
\text { Minor complications }\end{array}$ & $\begin{array}{l}\text { Nound } \\
\text { edge } \\
\text { treated conservatively } \\
\text { superficial } \\
\text { necrosis } \\
\text { necrosis }\end{array}$ & $\begin{array}{l}\text { As } \\
\text { above }\end{array}$ & None & None & None \\
$\begin{array}{l}\text { Major complications } \\
\text { requiring readmission } \\
\text { and/or reoperation }\end{array}$ & None & None & None & None & None \\
\hline
\end{tabular}

was 53 years. All of the patients made an informed decision to undergo implant based reconstruction after reviewing the reconstruction literature and detailed discussion with the specialist breast care nurse.

The details of patient related factors such as age, BMI, smoking status, co-morbidities, drug intake including steroid intake, alcohol consumption, skin quality, contralateral breast surgery, degree of ptosis, and knowledge about post-operative radiotherapy and its implications are given in Table 1.

Surgery related factors such as antibiotic prophylaxis (intra-operative and post-operative), skin prep used, method of dissection to raise the dermal sling and mastectomy flap, mastectomy specimen weight, cavity washout, change of gloves, laminar flow usage, type and number of drains used, duration for which drains were left in, frequency of post-operative follow up are detailed in Table 2.
The details of the hospital stay, immediate postoperative issues, tumour related factors, adjuvant, neoadjuvant treatments as well as further surgery planned are given in Tables 3, 4 and 5.

\section{Surgical technique}

The patients were marked with a standard Wise pattern incision, with a 7.5-9 $\mathrm{cm}$ vertical incision (depending on the patient's body habitus). Once de-epithelialisation of the skin was done, skin flaps, and dermal sling were raised and the breast disc was lifted from the pectoralis major and the mastectomy was performed in the standard manner.

The pectoralis major muscle was then raised by dividing it inferiorly and medially at the level of the infra mammary fold and a sub pectoral pocket was created. The synthetic non biological mesh (Ti Loop ${ }^{\circ}$ ) was fixed to the pectoralis muscle with $2 / 0$ absorbable sutures to complete the pocket. The permanent fixed volume implant chosen was placed in the pocket and the mesh was fixed to the inframammary fold as well as laterally along the anterior axillary line to prevent lateral displacement.

Finally the dermal sling overlying the mesh was fixed to the muscle and the wound closed in layers with two low pressure vacuum drains. Patients were advised to wear a support bra for 6 weeks.

The technique is summarized in Figs. 1 and 2.

\section{Complications}

There were no major complications and the only minor complication encountered was " $\mathrm{T}$ " junction and skin edge necrosis which settled with conservative measures.

Table 4 Tumour related factors

\begin{tabular}{|c|c|c|c|c|c|}
\hline & Patient 1 & Patient 2 & Patient 3 & Patient 4 & Patient 5 \\
\hline $\begin{array}{l}\text { Size } \\
\text { (invasive + } \\
\text { in situ) }\end{array}$ & $83 \mathrm{~mm}$ & $\begin{array}{l}\mathrm{R}-40 \mathrm{~mm}, \\
\mathrm{~L}-8 \mathrm{~mm}\end{array}$ & $9 \mathrm{~mm}$ with $\mathrm{ADH}$ & $\begin{array}{l}7 \mathrm{~mm} \text { invasive and } \\
100 \mathrm{~mm} \text { in situ }\end{array}$ & R-100 mm, L-55 mm \\
\hline Grade & 2 & $R-3, L-2$ & 3 & 3 & 3 \\
\hline Type & $\begin{array}{l}\text { Mixed ductal with } \\
\text { lobular features }\end{array}$ & $\begin{array}{l}\text { R-ductal, } \\
\text { L-lobular }\end{array}$ & Invasive ductal & Invasive micropapillary & $\begin{array}{l}\text { Invasive lobular } \\
\text { carcinoma }\end{array}$ \\
\hline LVI & Positive & Negative & Negative & Negative & Positive both sides \\
\hline $\begin{array}{l}\text { Lymph node } \\
\text { status }\end{array}$ & $1 / 1$ & $\begin{array}{l}\mathrm{R}-0 / 4, \\
\mathrm{~L}-0 / 3\end{array}$ & $0 / 2$ & $0 / 2$ & $\begin{array}{l}\mathrm{R}-2 / 4 \\
\mathrm{~L}-2 / 4\end{array}$ \\
\hline ER status & 7 & $R-2, L-7$ & 8 & 0 & R-8, L-8 \\
\hline PR status & 8 & $\begin{array}{l}\text { R-NK, } \\
\text { L-6 }\end{array}$ & 8 & 0 & $R-6, L-8$ \\
\hline \multirow[t]{2}{*}{ HER2 status } & Negative & R-Positive & Negative & Positive & Negative on both sides \\
\hline & & L-Negative & & & \\
\hline
\end{tabular}


Table 5 Adjuvant and neoadjuvant treatment and further surgery planned

\begin{tabular}{|c|c|c|c|c|c|}
\hline & Patient 1 & Patient 2 & Patient 3 & $\begin{array}{l}\text { Patient } \\
4\end{array}$ & $\begin{array}{l}\text { Patient } \\
5\end{array}$ \\
\hline $\begin{array}{l}\text { Neoadjuvant } \\
\text { chemotherapy }\end{array}$ & No & Yes & No & No & No \\
\hline $\begin{array}{l}\text { Neoadjuvant endocrine } \\
\text { therapy }\end{array}$ & No & No & No & No & No \\
\hline Adjuvant chemotherapy & Yes & No & No & No & Yes \\
\hline $\begin{array}{l}\text { Adjuvant endocrine } \\
\text { therapy }\end{array}$ & Planned & Yes & Yes & No & Yes \\
\hline Adjuvant radiotherapy & Planned & Yes only to the right & No & No & Yes \\
\hline Targeted therapy & No & Yes & No & No & No \\
\hline $\begin{array}{l}\text { Further surgery planned for } \\
\text { cancer }\end{array}$ & $\begin{array}{l}\text { Planned (completion axillary } \\
\text { clearance) }\end{array}$ & $\begin{array}{l}\text { Possible free flap reconstruction- } \\
\text { patient choice }\end{array}$ & $\begin{array}{l}\text { Patient not keen on } \\
\text { symmetrisation }\end{array}$ & No & No \\
\hline
\end{tabular}

Four out of the five patients have had 3 months follow up. The fifth patient had surgery less than 3 months ago.

Patient reported outcome measures (PROMS) were assessed in four patients with breast Q questionnaire after obtaining informed consent 3 months post-operatively. The details are given in Table 6. The last patient declined consent for evaluation.

\section{Results}

All five patients were satisfied with the care and information they received. They were also satisfied with the cosmetic outcome from the reconstruction at this early follow up although admittedly this may change with longer follow up as well as with adjuvant radiotherapy.

A random selection of 15 allied health professionals and administrative staff, who were not directly involved in patient care, were asked to score the cosmetic outcome in four patients (one patient declined post-operative photographs). They were shown photographs of the breasts 3 months post-op and asked to score them between 1 and 10, where 1 = poor cosmetic appearance and $10=$ excellent cosmetic appearance. In general, the scores were very encouraging with the average rating being 7.4-7.7. However the small sample size should be taken into context. The full details are given in Table 7 .

\section{Conclusion}

The availability of biological and non biological meshes have improved the cosmetic outcome of implant based reconstruction. The use of the mesh as a hammock in the lower pole and attaching it to the divided pectoralis major muscle enables us to reconstruct the breast using with larger volume implants with much less discomfort, quicker recovery, and better cosmetic outcome. This also avoids donor site scar and its associated morbidity in patients who are not keen to have other forms of reconstruction.

Our initial experience suggests that this technical innovation is an excellent alternative for patients with ptosis where skin reduction is needed. This negates the need to raise the serratus anterior muscle as required when the dermal sling alone is used for implant based reconstruction. This increases the post-operative pain considerably compared to our technique. In this method, the patient's own dermis can be used as a biological mesh to cover the non-biological mesh along the Wise pattern scar line, thereby protecting the mesh, and the implant in the unfortunate incidence of wound complications and providing an additional layer of protection with no increased morbidity from the procedure.

We accept that some critics might question the use of both the non biological mesh and the dermal sling and enquire what additional benefit is conferred by using both rather than one or the other. The answer is that with the dermal sling it is not always possible to achieve complete closure for the implant laterally and medially. This necessitates the need to raise the serratus anterior muscle which causes reasonable discomfort at least in the initial post-operative period. Our technique avoids the need to disturb serratus anterior. The use of a non biological mesh is also associated with lower rates of post-operative seroma formation which require aspiration. This is thought to be due to the perforations which most biological meshes lack with the exception of the fenestrated bovine acellular dermal matrix.

We acknowledge that no definite conclusion can be made from our initial experience of combining non biological mesh and dermal sling in patients having implant based reconstruction. However this procedure could be considered as an alternative to using biological mesh or dermal sling in implant based reconstruction in select 
Skin reducing, nipple sacrificing Wise pattern mastectomy and immediate breast reconstruction with implant, non biological mesh (Ti Loop®) and lower pole dermal sling

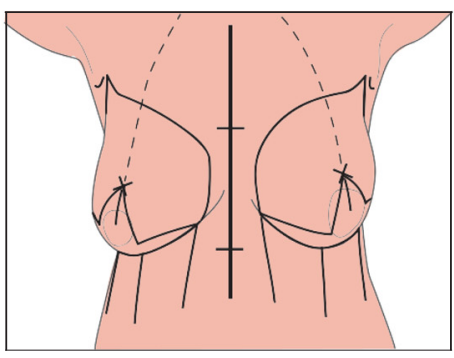

1. Breast with preoperative markings

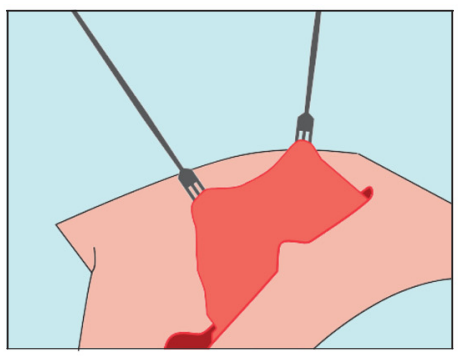

3. Skin flaps and dermal sling raised for mastectomy

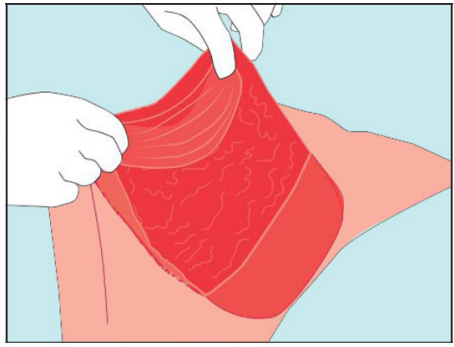

5. Pectoralis major muscle divided at infra mammary fold and medially raising sub pectoral pocket

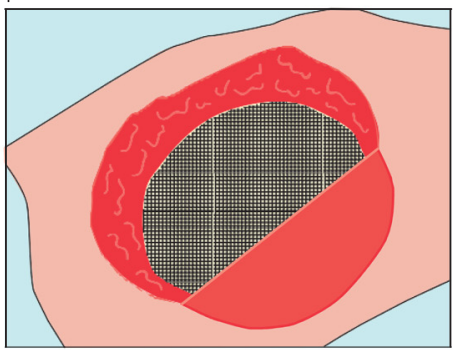

7. Breast implant in place of the sub

pectoral $/$ mesh space with mesh fixed to the infra mammary fold

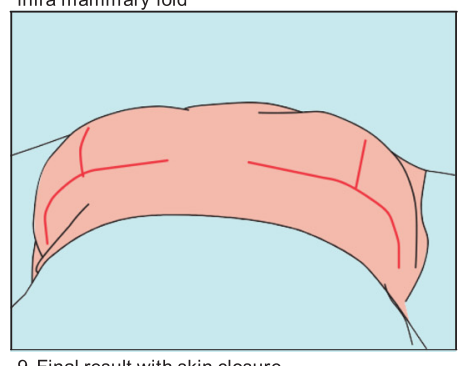

9. Final result with skin closure

Fig. 1 Schematics step by step summary of surgical technique

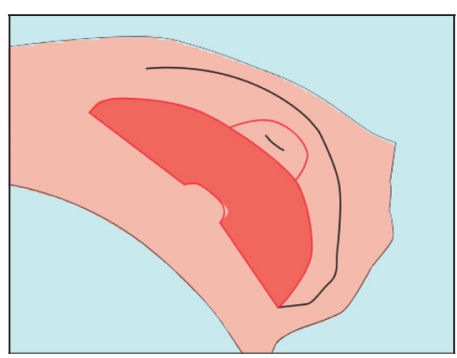

2. Area de-epithelialised for dermal sling

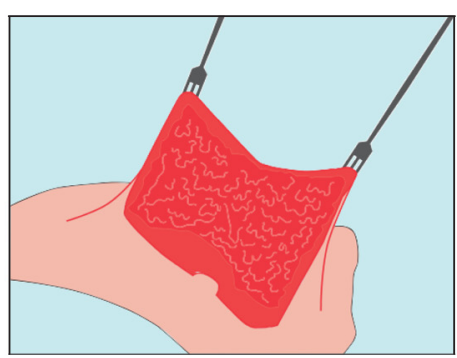

4. Mastectomy cavity with skin flaps pulled for demonstration

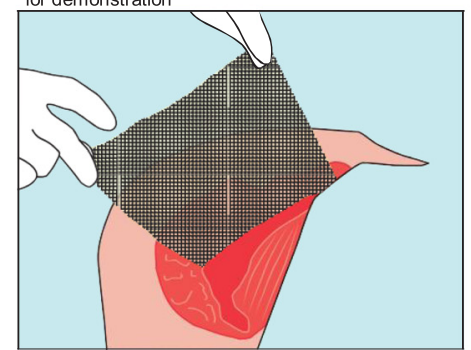

6. Non biological mesh fixed to the freed pectoralis major muscle

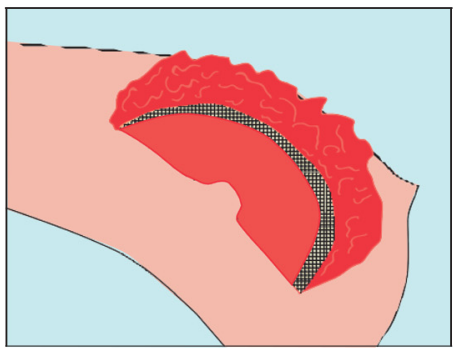

8. Dermal sling fixed to the pectoralis muscle

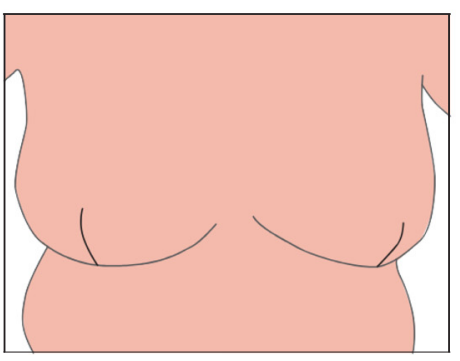

10. Two weeks post-op 
Skin reducing, nipple sacrificing Wise pattern mastectomy and immediate breast reconstruction with implant, non biological mesh (Ti Loop ) and lower pole dermal sling.

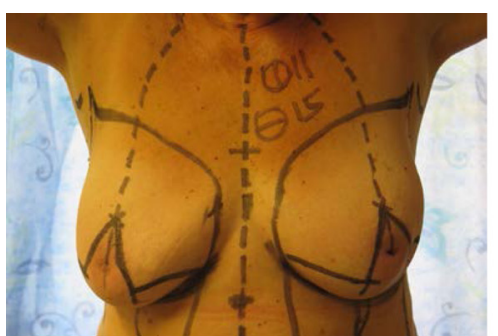

1. Breast with pre-operative markings

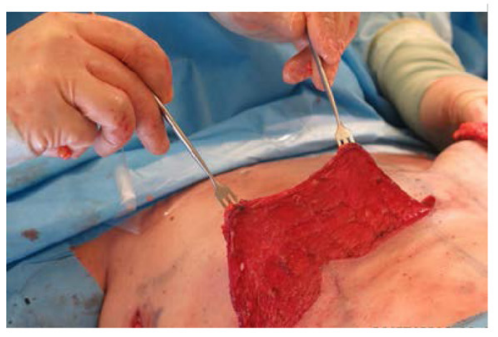

3. Skin flaps and dermal sling raised for mastectomy

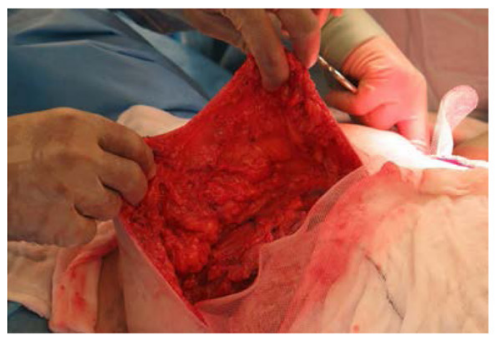

5. Pectoralis major muscle divided at the infra-mammary fold and ready for the mesh to be fixed to the free end

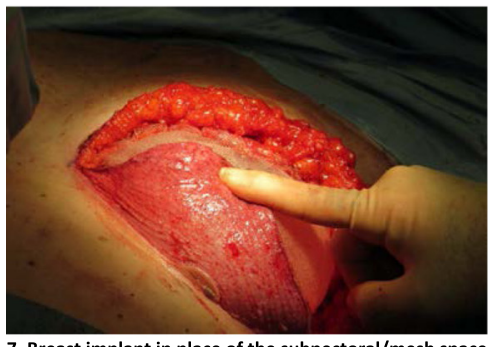

7. Breast implant in place of the subpectoral/mesh space with the dermal sling ready to be fixed to the pectoralis major muscle

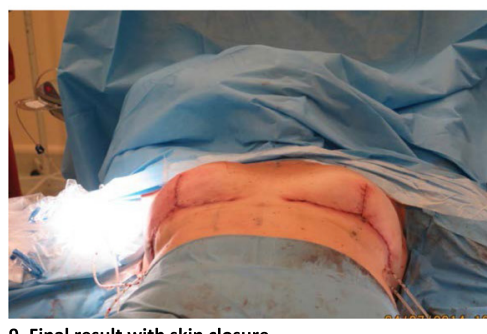

9. Final result with skin closure

Fig. 2 Illustrations of the step by step summary of surgical technique

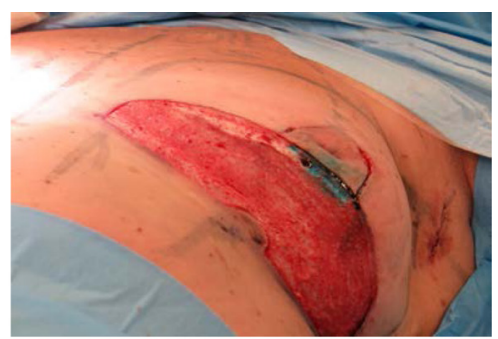

2. Area de-epithelialised for dermal sling

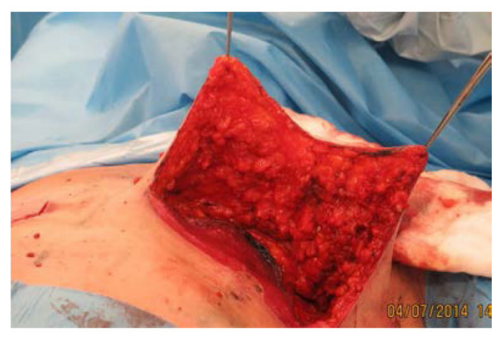

4. Mastectomy cavity shown with skin flaps raised

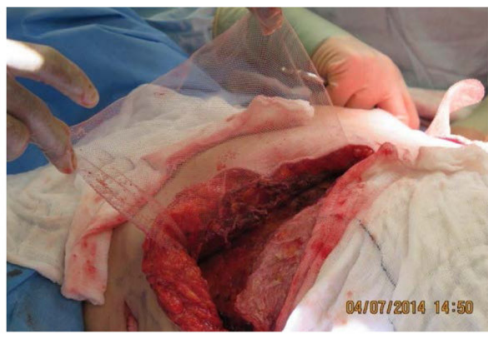

6. Non biological mesh fixed to the freed pectoralis major muscle

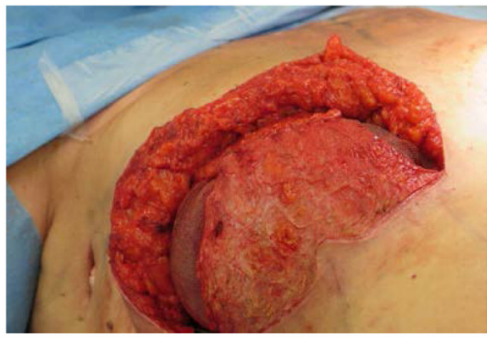

8. Fixing the dermal sling to the pectoralis major muscle

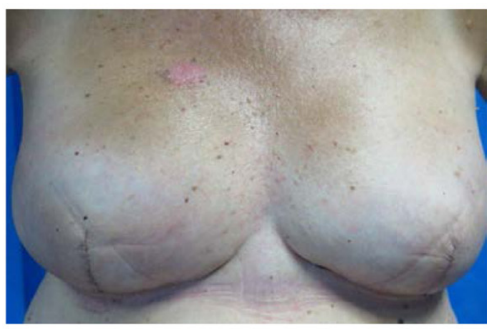

10. 2 weeks post op 
Table 6 PROMS (Patient Reported Outcome Measures at 3 months) ${ }^{a}$

\begin{tabular}{|c|c|c|c|c|}
\hline & $\begin{array}{l}\text { Patient } \\
1\end{array}$ & Patient 2 & Patient 3 & $\begin{array}{l}\text { Patient } \\
4\end{array}$ \\
\hline $\begin{array}{l}\text { Information given about } \\
\text { mastectomy and } \\
\text { reconstruction including } \\
\text { risks and benefits }\end{array}$ & $\begin{array}{l}\text { Right } \\
\text { amount }\end{array}$ & $\begin{array}{l}\text { Right } \\
\text { amount }\end{array}$ & $\begin{array}{l}\text { Right } \\
\text { amount }\end{array}$ & $\begin{array}{l}\text { Right } \\
\text { amount }\end{array}$ \\
\hline $\begin{array}{l}\text { Management of pain in the } \\
\text { first } 24 \mathrm{~h} \text { and during the } \\
\text { first week }\end{array}$ & $\begin{array}{l}\text { Mild } \\
\text { pain }\end{array}$ & $\begin{array}{l}\text { Moderate } \\
\text { to severe } \\
\text { pain }\end{array}$ & Mild pain & $\begin{array}{l}\text { Mild } \\
\text { pain }\end{array}$ \\
\hline $\begin{array}{l}\text { Unplanned readmission or } \\
\text { surgery }\end{array}$ & None & None & None & None \\
\hline $\begin{array}{l}\text { Complications requiring } \\
\text { treatment on an outpatient } \\
\text { basis since discharge from } \\
\text { hospital }\end{array}$ & None & $\begin{array}{l}\text { Oral } \\
\text { antibiotics } \\
\text { for } \\
\text { infection }\end{array}$ & $\begin{array}{l}\text { Oral } \\
\text { antibiotics } \\
\text { for } \\
\text { infection }\end{array}$ & None \\
\hline $\begin{array}{l}\text { Number of visits to surgical } \\
\text { outpatients since discharge }\end{array}$ & 4 & 5 & 3 & 3 \\
\hline
\end{tabular}

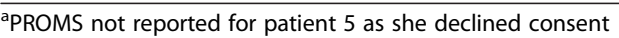

Table 7 Observer ratings of cosmetic appearance at 3 months $\left(1=\right.$ poor, $10=$ excellent $^{a}$

\begin{tabular}{lllll}
\hline & Patient 1 & Patient 2 & Patient 3 & Patient 4 \\
\hline Mean & 7.4 & 7.4 & 7.7 & 7.7 \\
Median & 7 & 8 & 8 & 8 \\
Mode & 7,8 & 8 & 8,9 & 8,9 \\
Range & $6-9$ & $5-9$ & $4-9$ & $4-9$ \\
\hline
\end{tabular}

${ }^{\mathrm{a}}$ Observer ratings not reported for patient 5 as she declined further follow up pictures

suitable patients. This technique is also very cost effective in units where the use of a biological mesh is prohibitive due to high expenses.

We intend to publish our results with more numbers and longer follow up in the future as we will continue to offer this procedure to selected patients who opt to have implant based breast reconstruction.

\section{Competing interests}

The authors declare that they have no competing interests.

\section{Authors' contributions}

HO: study concept RR: design, data collection, and manuscript FU: data collection and manuscript. All authors have read and approved the final manuscript.

\section{Acknowledgements}

The authors acknowledge Jessica Turvey, graphic designer based at the Clinical Media Centre, Mr. Samy Shaheed, Associate Specialist Breast Surgeon, and Dr. loannis Chavekes, Clinical Fellow Breast Surgery, Brighton, and Sussex University Hospitals NHS Trust for their assistance with the technical aspects of the surgery. All have given permission to be acknowledged.

Received: 30 November 2014 Accepted: 11 May 2015

Published online: 19 May 2015

\section{References}

1. Cancer Research UK. Breast cancer statistics. http://www.cancerresearchuk.org/ cancer-info/cancerstats/types/breast/?script=true Accessibility verified 27 June 2014
2. Jeevan R, Cromwell DM, Browne JP, Trivella M, Pereira J, Caddy CM, et al. Regional variation in use of immediate breast reconstruction after mastectomy for breast cancer in England. Eur J Surg Oncol. 2010;36(8):750-5.

3. Sheflan M, Brown I. Immediate implant-based breast reconstruction using variable lower pole support. In: Urban C, Rietjens M, editors. Oncoplastic and reconstructive breast surgery. Italy: Springer-Verlag; 2013. p. 235-52.

4. Johnson RK, Wright CK, Gandhi A, Charny MC, Barr L. Cost minimisation analysis of using acellular dermal matrix (Strattice ${ }^{T M}$ ) for breast reconstruction compared with standard techniques. Eur J Surg Oncol. 2013;39(3):242-7.

5. Dieterich M, Dieterich H, Timme S, Reimer T, Gerber B, Stubert J. Using a titanium-coated propylene mesh (TiLOOP® Bra) for implant-based breast reconstruction: case report and histological analysis. Arch Gynecol Obstet. 2012;286(1):273-6.

6. Dieterich M, Paepke S, Zwiefel K, Dieterich H, Blohmer J, Faridi A, et al. Implant-based breast reconstruction using a titanium-coated polypropylene mesh (TiLOOP Bra): a multicentre study of 231 cases. Plast Reconstr Surg. 2013;132(1):8e-19.

7. Dieterich M, Reimer T, Dieterich H, Stubert J, Gerber B. A short-term follow-up of implant based breast reconstruction using a titanium-coated polypropylene mesh (TiLOOP® Bra). Eur J Surg Oncol. 2012;38(12):1225-30.

8. Paepke S, Klein E, Paepke D, Kiechle M, Dieterich M. Titanized polypropylene mesh Tiloop ${ }^{\circledast}$ Bra in reconstructive breast surgery-indication and complication rate. Eur J Surg Oncol. 2014;40(5):622.

9. Waheed S, Barry P. Initial experience of the use of a titanium-coated polypropylene mesh (TiLOOP® Bra) for immediate implant-based breast reconstruction. Eur J Surg Oncol. 2013;39(5):505.

10. Goyal A, Wu JM, Chandran VP, Reed MWR. Outcome after autologous dermal sling-assisted immediate breast reconstruction. Brit J Surg. 2011;98(9):1267-72.

\section{Submit your next manuscript to BioMed Central and take full advantage of:}

- Convenient online submission

- Thorough peer review

- No space constraints or color figure charges

- Immediate publication on acceptance

- Inclusion in PubMed, CAS, Scopus and Google Scholar

- Research which is freely available for redistribution 